\title{
ANALISIS FAKTOR-FAKTOR YANG MEMPENGARUHI KONSUMSI BERAS DI KECAMATAN TEMBILAHAN KABUPATEN INDRAGIRI HILIR
}

\author{
Tina Fitriani ${ }^{1}$, Partini Partini ${ }^{2}$ \\ ${ }^{1,2}$ Program Studi Agribisnis Fakultas Pertanian UNISI \\ e-mail:green_tien2@yahoo.com
}

\begin{abstract}
ABSTRAK
Beras merupakan bahan pangan pokok bagi sebagian besar penduduk Indonesia. Walaupun terdapat alternatif bahan pangan lain seperti sagu, namun bagi masyarakat Kecamatan Tembilahan, peran beras tidak tergantikan sebagai sumber utama karbohidrat. Penelitian ini dilakukan pada bulan Januari sampai April 2017 di Kecamatan Tembilahan Kabupaten Indragiri Hilir. Tujuan penelitian ini adalah (1) untuk mengetahui faktor-faktor yang mempengaruhi konsumsi beras; (2) untuk mengetahui besarnya pengaruh faktor-faktor tersebut terhadap konsumsi beras di Kecamatan Tembilahan. Metode analisis data yang digunakan adalah regresi linear berganda. Hasil penelitian menunjukkan bahwa faktor-faktor yang mempengaruhi konsumsi beras di Kecamatan Tembilahan adalah jumlah anggota keluarga ( $\alpha=1 \%$ ) dan merk $(\alpha=20 \%)$ dengan koefisien regresi masing-masing 5,47 dan -3,55 sedangkan variabel harga dan pendapatan tidak berpengaruh signifikan.
\end{abstract}

Kata kunci : Beras, konsumsi

\section{ABSTRACT}

Rice is main food for Indonesian people. Althaught there is substitute for it like sagoo, but people in Subdistrict of Tembilahan cannot substitute rice with another food. This research was condusted on January until April 2017 in Subdistrict of Tembilahan Indragiri Hilir. The purposes of research are (1) to determine the factors that affecting of rice consumption in Subdistrict of Tembilahan and (2) to determine regression coeffisient each variabel that affecting consumption rice in Subdistrict Tembilahan. The research result showed that factors that affecting of rice consumption are number of family $(\alpha=1 \%)$ and brand $(\alpha=20 \%)$ with coefficient of regression 5,47 and -3,55.

Keywords : rice, consumption

\section{PENDAhUluan}

Beras merupakan bahan pangan pokok bagi sebagian besar penduduk Indonesia. Beras mengandung nilai gizi lebih baik dibandingkan dengan makanan pokok lainnya. Oleh karena itu, komoditas beras dapat dipergunakan untuk memperbaiki gizi masyarakat yang umumnya masih kekurangan energi dan protein (Amang, 1999).

Komoditi beras bagi masyarakat Indonesia bukan saja merupakan bahan pangan pokok, tetapi sudah merupakan komoditi sosial. Oleh karena itu, 
perubahan perubahan yang terjadi pada beras akan begitu mudah mempengaruhi kehidupan sosial-ekonomi yang lain. Perhatian pemerintah terhadap beras sudah lama dimulai dan bahkan setelah Indonesia merdeka, perhatian terhadap beras ini sudah menjadi program prioritas.

Bagi masyarakat Tembilahan, beras merupakan makanan pokok dan hampir tidak bisa digantikan dengan barang lain, sehingga berapapun harga beras masyarakat akan membelinya. Sebagai komoditas dengan permintaan yang inelastis, perubahan harga hampir tidak menyebabkan perubahan jumlah permintaan konsumen. Jika ketersediaan kurang, harga langsung naik karena konsumen tidak melakukan penyesuaian atas konsumsinya (Krisnamurthi, 2006). Konsumen juga tidak bisa mengurangi permintaannya ketika harga meningkat karena komoditas pangan/pertanian tersebut menjadi kebutuhan pokok. Kondisi ini membuat harga komoditas menjadi sangat sensitif terhadap shock, baik dari sisi penawaran maupun permintaan, termasuk indirect shock yang berpengaruh secara tidak langsung seperti gangguan distribusi. (Prastowo, 2008).

Peranan pemerintah yang dilimpahkan kepada Bulog sebagai lembaga penyangga bertujuan untuk memantau, menjaga dan menstabilkan harga dan pasokan beras di pasar ternyata belum mampu berperan secara signifikan akibat lemahnya kemampuan manajerial pengelola sehingga sering terjadi gejolak harga di pasar yang cukup meresahkan masyarakat.

Meningkatnya jumlah penduduk, akan berdampak langsung terhadap jumlah konsumsi beras. Mangahas dalam Benu (1996) menyatakan bahwa jumlah penduduk merupakan determinan utama dari kenaikan dalam permintaan produk pertanian sehingga jika suatu wilayah dengan kebutuhan pangan pokoknya adalah beras maka peningkatan jumlah penduduk akan semakin meningkatkan permintaan terhadap beras. Jumlah penduduk dan konsumsi beras di Kecamatan Tembilahan tersaji pada Tabel 1.

Tabel 1.Konsumsi Beras dan Jumlah Penduduk di Kecamatan Tembilahan Kabupaten Indragiri Hilir tahun 2011-2015.

\begin{tabular}{ccc}
\hline Tahun & Jumlah penduduk (jiwa) & Konsumsi beras ( ton ) \\
\hline 2011 & 72.001 & $7.758,83$ \\
2012 & 72.424 & $7.816,00$ \\
2013 & 64.113 & $6.919,07$ \\
2014 & 73.092 & $7.776,99$ \\
2015 & 74.087 & $7.882,86$ \\
\hline
\end{tabular}

Sumber: BPS Kabupaten Indragiri Hilir, 2015

Mengkonsumsi beras merupakan bentuk nyata dari budaya masyarakat untuk kehidupan yang lebih baik, ini berbanding lurus dengan jumlah konsumsi beras, akan tetapi konsumsi beras masih jauh diatas produksi beras yang mengalami fluktuasi.
Berdasarkan latar belakang tersebut, tujuan penelitian ini adalah (1) untuk mengetahui faktor faktor yang mempengaruhi konsumsi beras di Kecamatan Tembilahan dan (1) untuk mengetahui besarnya pengaruh faktorfaktor tersebut terhadap konsumsi beras 
di Kecamatan Tembilahan Kabupaten Indragiri Hilir.

\section{METODOLOGI PENELITIAN}

\subsection{Waktu dan Tempat Penelitian}

Penelitian dilakukan di tiga kelurahan yaitu Kelurahan Tembilahan Kota, Kelurahan Tembilahan Hilir, dan Kelurahan Sungai Beringin pada bulan Januari sampai April 2017. Penentuan lokasi dilakukan secara purposive dengan pertimbangan ketiga kelurahan tersebut memiliki jumlah penduduk terbesar di Kecamatan Tembilahan.

\subsection{Metode Pengambilan Sampel}

Penentuan sampel dilakukan secara acak dan penentuan jumlahnya dilakukan dengan metode Slovin dengan rumus sebagai berikut:

$$
n=\frac{\mathrm{N}}{1+\mathrm{Ne}^{2}}
$$

Dimana:

$\mathrm{n}=$ Jumlah sampel

$\mathrm{N}=$ Jumlah populasi

$\mathrm{e}=$ persen kelonggaran ketidaktelitian karena kesalahan pengambilan sampel yang masih dapat ditolerir/diinginkan (Umar,2013)

Berdasarkan rumus, apabila menggunakan batas kesalahan dapat ditoleransi sebesar $17 \%$ persen, dengan jumlah rumah tangga yang ada di Kecamatan Tembilahan sebanyak 13.687 rumah tangga, maka jumlah sampel yang terhitung adalah sebagai berikut:

$$
\begin{aligned}
& n=\frac{\mathrm{N}}{1+\mathrm{Ne}^{2}} \\
& n=36
\end{aligned}
$$

Dari 36 sampel rumah tangga di Kecamatan Tembilahan masing masing Kelurahan diambil 12 sampel.

\subsection{Jenis dan Sumber Data}

Data primer data yang diperoleh langsung dari responden melalui wawancara dengan menggunakan daftar pertanyaan atau kuisioner yang telah disiapkan sebelumnya, wawancara dilakukan terhadap rumah tangga di Kecamatan Tembilahan yang meliputi data harga beras, anggota keluarga, pendapatan keluarga dan pengaruh merk.

Data skunder ini di peroleh data dari Badan Pusat Statitik dan Badan Pelaksana Penyuluh dan Ketahanan Pangan Kabupaten Indragiri Hilir yang meliputi data jumlah penduduk, jumlah rumah tangga dan jumlah permintaan beras.

\subsection{Metode Analisis Data}

Analisis data dilakukan dengan menggunakan metode regresi linear berganda. Model regresi dirumuskan sebagai berikut:

$Y=a+b_{1} X_{1}+b_{2} X_{2}+b_{3} X_{3}+b_{4} X_{4}+e$.

di mana :

$\mathrm{Y}=$ Jumlah Permintaan beras $(\mathrm{kg})$

$\mathrm{a}=\operatorname{Konstanta}($ Intercept $)$

$\mathrm{X}_{1}=$ Harga beras $(\mathrm{Rp} / \mathrm{kg})$

$\mathrm{X}_{2}=$ Jumlah anggota keluarga (jiwa)

$\mathrm{X}_{3}=$ Pendapatan keluarga (Rp/bulan)

$\mathrm{X}_{4}=\operatorname{Merk}$ (Dummy)

$0=$ tidak mempertimbangkan merk dalam pembelian beras

$1=$ mempertimbangkan merk dalam pembelian beras.

$\mathrm{b}=$ Koefisien regresi

$\mathrm{e}=$ Faktor kesalahan

Untuk mengetahui goodness of fit model dapat dilihat dari :

1. Koefisien Determinasi $\left(\mathrm{R}^{2}\right)$, digunakan untuk mengukur seberapa jauh kemampuan model dalam menerangkan variasi variable dependen

2. Uji F, untuk mengetahui apakah variabel-variabel independen secara 
simultan berpengaruh terhadap variabel dependen. Jika $\mathrm{F}$ hitung $>\mathrm{F}$ tabel.

3. Uji t, untuk menguji pengaruh parsial dari variabel independen terhadap variabel dependen.

Selanjutnya untuk mengetahui ada tidaknya pelanggaran asumsi klasik dilakukan dengan:

1. Uji Multikolinearitas.

Nilai cutoff yang umum dipakai untuk menunjukkan adanya multikolonieritas adalah nilai tolerance $<0,10$ atau sama dengan nilai VIF > 10 (Ghozali,2005).

2. Uji autokorelasi

Untuk mengetahui terjadanya autokorelasi digunakan nilai Durbin Watson (Dw) dengan ketentuan nilai : 0 - 1,224 (Ada autokorelasi),
1,224 - 1,553 (daerah keraguraguan), 1,553 - 2,447 (Tidak ada Autokorelasi), 2,447 - 2,776

(Daerah Keragu-raguan) dan 2,776

- 4 (Ada Autokorelasi)

3. Uji heteroskedastisitas

Untuk mengetahui terjadinya heteroskedastisitas digunakan metode Glejser dengan ketentuan jika nilai signifikansi variabel independen dengan absolut residual lebih dari 0.05 maka tidak terjadi masalah heteroskedastisitas

\section{III.HASIL DAN PEMBAHASAN}

\subsection{Karakteristik Responden}

Karakteristik responden dalam penelitian ini meliputi umur, tingkat pendidikan dan pendapatan, disajikan pada Tabel 2.

Tabel 2. Karakeristik Responden

\begin{tabular}{clcc}
\hline No & Karaketeristik & Jumlah & Persentase (\%) \\
\hline A & Umur & & \\
1 & $20-30$ & 1 & 2,78 \\
2 & $31-40$ & 10 & 27,78 \\
3 & $41-50$ & 15 & 41,67 \\
4 & $>50$ & 10 & 27,78 \\
\hline B & Pendidikan & & \\
1 & SD & 8 & 22,22 \\
2 & SLTP & 10 & 27,78 \\
3 & SLTA & 13 & 36,11 \\
4 & SARJANA & 5 & 13,38 \\
\hline C & Pendapatan & & \\
1 & Rp. 2.000.000-3.000.000 & 11 & 30,56 \\
2 & Rp. 3.000.001-4.000.000 & 11 & 30,56 \\
3 & Rp. 4.000.001-5.000.000 & 4 & 11,11 \\
4 & Rp 5.000.001-6.000.000 & 3 & 8,33 \\
5 & $>$ Rp 6.000.000 & 7 & 19,44 \\
\hline
\end{tabular}

Tingkat pembelian konsumen sangat di pengaruhi oleh umur, orang akan mengubah pola pembeliannya selama umurnya terus bertambah demikian pula pada sampel konsumsi beras. Berdasarkan Tabel 2. Dapat dilihat bahwa sebagian besar responden berada pada usia diatas 30 tahun. Responden umumnya adalah ibu rumah tangga yang bertanggung jawab 
terhadap pembelian kebutuhan pokok dalam rumah tangga.

Selain umur, tingkat pendidikan akan mempengaruhi nilai-nilai yang dianutnya, cara berfikir, cara pandang bahkan persepsinya pada suatu masalah (Sumarwan, 2003). Sebagian besar responden berpendidikan SLTA $(36,11$ $\%$ ) selanjutnya SLTP $(27,78 \%)$, SD $(22,22 \%)$ dan Sarjana $(13,38 \%)$.

Karakteristik responden berikutnya adalah pendapatan. Menurut Pusparini (2013), pendapatan merupakan imbalan yang diterima oleh seseorang dari pekerjaan yanag dilakukannya untuk mencari nafkah. Penghasilan pada umumnya dalam bentuk uang, jumlah penghasilan yang menggambarkan daya beli seseorang, yang selanjut nya yang akan mempengaruhi pola konsumsi. Berdasarkan Tabel 2. terlihat bahwa pendapatan keluarga bervariasi dimana seluruh responden memiliki pendapatan keluarga lebih besar dari UMK Kabupaten Indragiri Hilir. Sebagian besar berada pada rentang $\mathrm{Rp} 2.000 .000$ - Rp 3.000.000 dan Rp >3.000.000 Rp 4.000.000.

\subsection{Hasil Analisis Regresi Linear}

Hasil analisis regresi linear faktorfaktor yang mempengaruhi konsumsi beras di Kecamatan Tembilahan disajikan pada Tabel 3.

Tabel 3. Faktor - Faktor Yang Mempengaruhi Konsumsi Beras

\begin{tabular}{lllll}
\hline No & Variabel & koefesien regresi & $\mathrm{t}$ - hitung & $\mathrm{t}$-sig \\
1 & Konstanta & 1,77 & 0,10 & 0,92 \\
2 & Harga beras & 0,001 & 0,64 & $0 ., 52$ \\
3 & Anggota keluarga & 5,47 & 8,63 & 0,000 \\
4 & Pendapatan & $-4,5157$ & $-1,08$ & 0,287 \\
$5 \quad$ Merk & $-3,5496$ & $-1,434$ & 0,162 \\
\hline \multicolumn{2}{r}{$\mathrm{R}^{2}=0,71 ;$ F hitung $=19,25 ;$} & & \\
$\quad \mathrm{a}=$ signifikan pada $\alpha=1 \% ;$ & & & \\
$\mathrm{d}=$ signifikan pada $\alpha=20 \%$ & &
\end{tabular}

Berdasarkan Tabel 3, maka dapat dituliskan model faktor-faktor yang mempengaruhi konsumsi beras di Kecamatan Tembilahan sebagai berikut:

$\mathrm{Y}=1,77+0,001 \mathrm{X}_{1}+5,47 \mathrm{X}_{2}-4,52 \mathrm{X}_{3}$ $-3,55 X_{4}+$ e.

Hasil analisis regresi menunjukkan bahwa nilai $\mathrm{R}^{2}$ model sebesar 0.71 yang berarti model dapat menjelaskan keragaman variabel terikat sebesar $71 \%$, sedangkan sisanya $29 \%$ diterangkan oleh variabel lain yang tidak termasuk dalam model ini. Hasil uji $\mathrm{F}$ sebesar 19,25 (probability 0.000.) hal ini menunjukkan bahwa secara serempak faktor-faktor yang mempengaruhi konsumsi beras (harga beras, jumlah anggota keluarga, pendapatan dan merk) berpengaruh nyata terhadap jumlah konsumsi beras di Kecamatan Tembilahan. Sedangkan untuk pengaruh variabel parsial dari hasil uji t diketahui bahwa variabel yang berpengaruh signifikan terhadap konsumsi beras adalah jumlah anggota keluarga $(\alpha=1 \%)$ dan merk $(\alpha=20 \%)$, sedangkan dua variabel lain yaitu pendapatan dan harga beras tidak berpengaruh signifikan terhadap konsumsi beras di Kecamatan Tembilahan.

Selanjutnya hasil uji pelanggaran asumsi klasik adalah sebagai berikut:

\section{Uji multikolineritas}

Asumsi multikolonearitas ini menguji apakah dalam model regresi 
ditemukan adanya korelasi antar variabel independen. Model regresi yang baik seharusnya tidak terjadi korelasi diantara variabel independen. Apabila terjadi multikolinearitas maka nilai estimasi parameter menjadi bias. Sehingga akan memberikan hasil verifikasi (pengujian hipotesis) yang tidak berguna bagi pengambilan keputusan (Gujarati, 2006).

Hasil pengujian multikolinearitas menunjukkan bahwa semua variabel tidak terjadi multikolinearitas dengan nilai VIF $<10$ seperti disajikan pada Tabel 3.

Tabel 3. Pengujian Multikolinearitas

\begin{tabular}{llc}
\hline No & \multicolumn{1}{c}{ Variable } & VIF \\
1 & Harga Beras & 2,94 \\
2 & Jumlah anggota & 1,10 \\
& keluarga & \\
3 & Pendapatan ) & 1,37 \\
4 & Merk ) & 3,41 \\
\hline
\end{tabular}

\section{Uji heteroskedastistas}

Metode OLS baik model regresi sederhana maupun berganda mangasumsikan bahwa variabel gangguan mempunyai rata-rata nol, mempunyai varian yang konstan dan variabel gangguan tidak saling berhubungan antara satu observasi dengan observasi lainnya sehingga menghasilkan estimator OLS yang BLUE (Gujarati, 2000).

Tabel 4. Pengujian Heteroskedastisitas

\begin{tabular}{llc}
\hline No & Variable & Signifikansi \\
1 & Harga Beras & 0,85 \\
2 & Jumlah anggota & 0,96 \\
& keluarga & \\
3 & Pendapatan ) & 0,41 \\
4 & Merk ) & 0,36 \\
\hline
\end{tabular}

Berdasarkan Tabel 4 dapat dilihat bahwa semua variabel tidak terjadi heterokedastisitas. Hal ini dapat dibuktikan dengan diperolehnya nilai signifikansi untuk masing-masing variabel yang lebih besar dari $5 \%$

\section{Uji autokorelasi}

Nilai Durbin- watsson (Dw) sebesar 1.635 yang berada pada interval nilai 1,553 - 2,447 yang berarti tidak ada autokorelasi.

\subsection{Variabel yang Mempengaruhi Konsumsi Beras}

Konsumsi dapat diartikan sebagai bagian pendapatan rumah tangga yang digunakan untuk membiayai pembelian aneka jasa dan kebutuhan lain. Konsumsi merupakan fungsi dari pendapatan siap pakai (disposable income). Dengan kata lain, fungsi konsumsi menunjukkan hubungan antara tingkat pengeluaran konsumsi dengan tingkat pendapatan yang siap dibelanjakan (Prasetyo, 2011). Hasil analisis regresi faktor-faktor yang mempengaruhi konsumsi beras di Kecamatan Tembilahan adalah sebagai berikut:

\section{Jumlah Anggota Keluarga}

Jumlah anggota keluarga berpengaruh signifikan positif dengan taraf kepercayaan 99\% $(\alpha=1 \%)$, dan koefisien regresi 5,47 artinya jumlah anggota keluarga bertambah 1 orang maka permintaan beras akan meningkat sebesar $5,47 \mathrm{~kg} / \mathrm{bln}$. Hal ini disebabkan karena apabila jumlah anggota keluarga bertambah maka permintaan beras akan semakin meningkat. Hal ini senada dengan penelitian yang dilakukan Herdiansyah (2016) bahwa jumlah penduduk berpengaruh positif dan signifikan terhadap permintaan beras. 


\section{Merk}

Merk berpengaruh terhadap konsumsi beras pada taraf $\alpha=20 \%$, artinya dalam melakukan pembelian beras konsumen mempertimbangkan merk. Menurut Tamporal dan Lee (2002), para konsumen akan memilih produk dan jasa yang berkualitas dimanapun dan kapan pun mereka mampu. Sekali mereka mencoba suatu merk, secara otomatis mereka akan menyamakan pengalaman ini dengan tingkat kualitas tertentu. Pengalaman yang menyenangkan akan menghasilkan ingatan yang baik terhadap merk tersebut.

\section{Harga Beras}

Harga beras tidak berpengaruh signifikan terhadap konsumsi beras di Kecamatan Tembilahan. Masyarakat tetap akan mengkonsumsi beras walaupun harga beras mengalamifluktuasi harga, karena beras merupakan makanan pokok masyarakat yang tetap akan dibeli oleh konsumen. Hasil penelitian Partini, et al (2013), menyatakan bahwa harga beras berpengaruh negatif tetapi dengan respon yang negatif. Hal ini mengindikasikan bahwa sebagai bahan kebutuhan pokok, jumlah permintaan beras tidak responsif terhadap perubahan harga.

\section{Pendapatan}

Menurut Sudarsono (1990), daya beli seseorang tergantung atas dua unsur pokok yaitu pendapatan yang dibelanjakan dan harga barang yang dikehendaki. Apabila jumlah pendapatan yang dibelanjakan oleh seseorang berubah maka jumlah barang yang diminta juga akan berubah demikian juga halnya harga barang yang dikehendaki juga dapat berubah.
Hasil analisis regresi menunjukkan bahwa pendapatan tidak berpengaruh signifikan terhadap konsumsi beras di Kecamatan Tembilahan. Hasil penelitian Partini, et al (2013) juga menunjukkan bahwa pendapatan tidak berpengaruh sidnifikan terhadap permintaan beras di Provinsi Riau. Hal ini menunjukkan bahwa pendapatan tidak berpengaruh signifikan terhadap jumlah konsumsi beras di Kecamatan Tembilahan. Hal ini dikarenakan seberapa besar pun pendapatan masyarakat mereka tetap akan mengkonsumsi beras.

\section{IV.PENUTUP}

\subsection{Kesimpulan}

1. Faktor-faktor yang mempengaruhi konsumsi beras di Kecamatan Tembilahan adalah variabel jumlah anggota keluarga $(\alpha=1 \%)$ dan merk $(\alpha=20 \%)$.

2. Koefisien regresi untuk setiap variabel yang berpengaruh terhadap konsumsi beras adalah sebagai berikut:

a. Jumlah anggota keluarga dengan koefesien regresi sebesar 5,47. Artinya apabila jumlah anggota keluarga bertambah 1 orang maka permintaan beras akan meningkat sebesar 5,47 kg. Hal ini disebabkan karena apabila jumlah anggota keluarga bertambah maka permintaan beras akan semakin meningkat.

b. Variabel merk berpengaruh signifikan negatif pada taraf $\alpha=20 \%$ dan koefisien regresi $-3,55$. Hal ini berarti merk memberikan pengaruh kepada konsumen dalam melakukan pembelian beras.

c. Variable harga dan pendapatan tidak berpengaruh signifikan. Hal ini dikarenakan beras merupakan kebutuhan pokok sehingga 
berapapun harga dan tingkat pendapatan seseorang tetap akan membelinya dengan perubahan yang tidak signifikan.

\section{DAFTAR PUSTAKA}

Amang,B dan M.H. Sawit.1999. Kebijakan Beras dan Pangan Nasional. Bogor. IPB Press.

Badan Pusat Statistik. 2015. Kabupaten Indragiri Hilir dalam Angka.

Gujarati, Damodar. 2006. Dasar dasar Ekonometika.Erlangga, Jakarta

Krisnamuthi, Bayu. 2006. Fakta dan Kebijakan Perberasan.

http://nasih.staff.ugm.ac.id. Diunduh 9 Maret 2017.
Prastowo, Nugroho J., Tri Yanuarti., Yoni Depari. 2005. Pengaruh Distribusi Dalam Pembentukan Harga Komoditas dan Implikasinya Terhadap Inflasi. Working Paper. Bank Indonesia.

Partini; Suardi Tarumun dan Ermi Tety. 2013. Analisis Faktor-faktor yang Mempengaruhi Penawaran dan Permintaan Beras di Provinsi Riau. Jurnal PEKBIS No.5 Vol.3, 170-178.

Sudarsono, 1990. Pengantar Ekonomi Mikro. LP3ES. Jakarta.

Tamporal, Paul, dan Lee, Kc, 2002, HiTech-Hi-Toch Branding, Terjemahan Anastasia. Jakarta:Selemba Empat 